Species of colonial birds found in Saskatchewan:

White Pelican

Double-crested Cormorant

Great Blue Heron

Black-crowned Night Heron

Herring Gull

Ring-billed Gull

Mew Gull

Bonaparte's Gull

Arctic Tern

Common Tern

Forster's Tern

Caspian Tern

Western Grebe

Eared Grebe

\section{SHARP-TAILED GROUSE FLIGHT SPEED}

ROBERT W. NERO,

546 Coventry Road, Winnipeg, Man. R3R $1 \mathrm{~B} 6$

One method of estimating the flight speed of birds is based on an accidental encounter with one or more travelling for some distance on a parallel course with a vehicle. On April 11, 1970, an opportunity arose to clock a Sharp-tailed Grouse by this method. This was at 3:30 p.m. while travelling on PTH 12 near Piney in extreme southeastern Manitoba. The bird was seen in flight for about a quarter of a mile before a bend in the road brought us onto parallel courses. I drove in excess of $70 \mathrm{mph}$ to overtake it, then paced it at a steady 55-60 $\mathrm{mph}$ for at least another quarter mile before it veered off. Its flight during this period was the alternated fast beat and glide typical of Sharp-tailed Grouse in normal distant flight. It was flying about 30 feet above the ground and was apparently not being pursued. Evidently it was moving to open fields to feed, for several other Sharptails were seen nearby feeding in cultivated land.

This observation permits an estimation of ground speed of 55-60 mph, but this needs to be qualified by a consideration of the wind speed and direction. Since the grouse was flying with the wind, estimated by weather authorities for that area and time at 11-15 mph, its air speed must have been about 45-50 mph.

\section{SPECIMEN OF A VARIED THRUSH AT LUSELAND, SASKATCHEWAN}

\author{
KIM B. FINLEY,
}

Box 8, Luseland, Sask.

On 25 September, 1975, a dead Varied Thrush was found beneath the window of a garage in Luseland, 105 miles west of Saskatoon. The thrush, which appears to be an adult female, was in excellent condition and had been dead for only a few hours. The specimen is being deposited at the Saskatchewan Museum of Natural History in Regina.

This bird constitutes the second known specimen record for this species in Saskatchewan. The first record consisted of an incomplete specimen of an adult male from Valley Centre, 60 miles east-southeast of Luseland. ${ }^{1}$ The date of the Luseland record falls medially in the period of previous fall records for the province. ${ }^{2}$ The majority of the Saskatchewan records for this species occur in the fall during the period 4 September to 14 November, possible indicating a wide autumn dispersal for this species.

'RENAUD, W. E. and D. H. RENAUD. 1975 Birds of the Rosetown-Biggar district, Saskatchewan. Sask. Nat. Hist. Soc., Spec. Publ. No. 9. $121 \mathrm{p}$.

"SEALY, SPENCER G. 1971. The Occurrences of some western birds in Saskatchewan. Blue Jay 29: 184-196. 